\title{
EFFECT OF FEED RESTRICTION WITH SUPPLEMENTATION OF PROBIOTIC WITH ENZYMES PREPARATION ON PERFORMANCE, CARCASS CHARACTERISTICS AND ECONOMIC TRAITS OF BROILER CHICKENS DURING FINISHER PERIOD
}

\author{
El-Faham A.I.; Nematallah G.M. Ali and M.A.M. Abdelaziz \\ Poultry Production Department, Faculty of Agriculture, Ain Shams University, Egypt. \\ Corresponding author: Mrwan Abdelaziz; E-mail: mrwanabdelaziz@agr.asu.edu.eg
}

(Received 26/2/2018, accepted 27/3/2018)

\section{SUMMARY}

\begin{abstract}
$\mathrm{T}$ The objective of this study was to investigate the response of broiler chicks to feed restriction at finisher period (5-6 weeks) of age and supplementation of (probiotic + enzymes preparation) on performance, carcass characteristics and economical traits. A total number of 180 Hubbard broiler chickens 5 weeks of age were weighed and divided into six dietary treatments of 30 chicken each with 3 replicates (10 chicken in each), in $2 \times 3$ factorial design as follow: T1: Chickens fed basal diet ad-libitum without supplementation, T2: Chickens fed basal diet ad-libitum + Zado ${ }^{\circledR}(0.5 \mathrm{Kg} /$ ton $)$, T3: Chickens fed basal diet ad-libitum + AmphiBact ${ }^{\circledR}$ $(0.5 \mathrm{Kg} /$ ton), T4: Chickens fed (T1 diet), restricted for 6 hours / day, T5: Chickens fed (T2 diet), restricted for 6 hours / day, T6: Chickens fed (T3 diet), restricted for 6 hours / day. The results indicated that: Productive performance of broiler chicks including live body weight (LBW); daily weight gain (DWG); feed conversion ratio $(\mathrm{FCR})$, performance index (PI), production efficiency factor (PEF), protein conversion ratio (PCR) and energy conversion ratio (ECR) were not affected significantly by feed restriction (R), feed supplementation, $(\mathrm{F})$ and interaction $(\mathrm{R} * \mathrm{~F})$ at experimental period (5-6 weeks of age). Daily feed intake (DFI) recorded a significant response due to feed restriction only. Carcass characteristics (edible parts, inedible parts, carcass cuts and drumstick traits) indicated that $(\mathrm{R}),(\mathrm{F})$ and interaction $\left(\mathrm{R}^{*} \mathrm{~F}\right)$ had no significant effects except dressed carcass and neck percentages. Economic evaluation showed that, chicks fed diet supplemented with (Zado®, $0.5 \mathrm{Kg}$ / ton) in either ad-libitum or restricted regime had the best relative economic efficiency (REE) and mean economic efficiency of all restricted-fed groups, increased (REE) by $3.4 \%$ as compared with the corresponding values of the ad-libitum groups. Based on the experimental results, it is concluded that supplementing broiler chicks under ad-libitum or restricted-fed regime with $(\mathrm{Zado} \circledast, 0.5 \mathrm{Kg} / \mathrm{ton})$ could be better approach to improve relative economic efficiency during finisher period.
\end{abstract}

Keywords: Broiler chicks- probiotic-feed restriction- growth performance - finisher

\section{INTRODUCTION}

The rising consumption of poultry meat and eggs in Egypt has been the main drivers for the poultry industry to change both in scale and structure (Abd El-Galil et al. 2017 and Saxowsky and Duncan, 1998). However, the shortage and costs of feedstuffs has been found to be one of the main factors limiting the development and expansion of the poultry industry (Emenalom, 2004). Feed is a substantial part of poultry production and it can represent $80 \%$ of the total costs of production (Scott et al., 1982 and Longe, 2006).

Feed restriction may be the way to decreased economic cost and also, suitable under environmental heat stress, El-Sagheer and Makled (2005) concluded that, the most suitable feeding regime during high ambient temperature is achieved by feed withdrawal for about 6 hours daily; between 9.00 a.m. and 3.00 p.m. from 2 to 7 weeks of age, as presenting best economically efficient compared to other feed restriction regimes. Also, using this regime was associated with a reduction in fat deposition and with no mortalities. However, Azarnik et al. (2010) reported that feed restriction significantly reduced body weight gain and feed consumption while had no significant effect on feed conversion of broilers. In contrast, Hassanien (2011) reported that feed restriction systems insignificantly affect live body weight, body weight gain and feed conversion at starter period and significantly reduced feed consumption and improving economic efficiency. Recently, Hassanien and Elnagar (2011) reported that feed restriction at different chickens age can improve 


\section{El-Faham et al.}

body weight, body weight gain and feed consumption and economic efficiency, while did not have effect on feed efficiency and carcass traits.

On the other hand, probiotic is a substance that contains microorganisms or bacteria that have a positive influence on improving the intestinal microbial balance (Czerwinski et al., 2010), inhibit the growth of harmful bacteria (Biggs and Parsons, 2008), helps overcome stress (Rahimi et al. 2007 and 2009), improves growth (Awad et al., 2009) and feed conversion ratio (Midilli et al., 2008). Enzymes able to break down the cell wall matrix and release of nutrients encapsulated in cell walls or incorporate into the cell wall itself (Cowieson and Adeola, 2005). Supplementation with enzymes can help to eliminate the effect of antinutritional factors and improve the utilization of dietary energy and amino acids, resulting in improved performance of chicks (Cowieson et al., 2006 and Yu et al., 2007). Broiler diets supplemented with symbiotic as growth promoter appeared to have better performance than using probiotic or prebiotic solely and produced healthy broiler meat products for human consumption (Salem et al., 2012).

Therefore, the present study was designed to investigate the response of broiler chicks to feed restriction at finisher period and supplementation of (Probiotic + enzymes preparation) on broiler performance, carcass characteristics and economical traits.

\section{MATERIALS AND METHODS}

The present experiment was performed in Agricultural Experiments and Research Station at Shalakan, Poultry Production Experimental Unit, Faculty of Agriculture, Ain Shams University.

\section{Experimental design}

A total of 180 Hubbard broiler chickens 5 weeks of age were randomly assigned to one of six dietary experimental group of ( 30 chicken each) and each treatment had three replicates (10 chicken in each), in $2 \mathrm{x}$ 3 factorial design. Experiment was conducted from 5 to 6 weeks of age. Chickens were weighed and assigned to 6 treatments with an average live body weight ranged between $1532.13 \pm 54.71$ and $1571.67 \pm$ $71.87 \mathrm{~g}$. The six treatments were as follows:

T1 Chickens fed basal diet ad-libitum without feed supplements

T2 Chickens fed basal diet ad-libitum + Zado ${ }^{\circledR}(0.5 \mathrm{Kg} / \mathrm{ton})$

T3 Chickens fed basal diet ad-libitum + AmphiBact@ $(0.5 \mathrm{Kg} /$ ton $)$

T4 Chickens fed (T1 diet) and restricted for 6 hours / day.

T5 Chickens fed (T2 diet) and restricted for 6 hours / day.

T6 Chickens fed (T3 diet) and restricted for 6 hours / day.

Zado® is a commercial product that contains:

- Anaerobic bacteria; Ruminococcus flavefaciens.

- Enzymes; Cellulase, Xylanase, Alpha Amylase and Protease.

AmphiBact ${ }^{\circledR}$ is a commercial product that contains:

- Lactic acid bacteria; Lactobacillus acidophilus, Lactobacillus plantarum and Bifidobacterium bifidum.

- Enzymes; Amylase, cellulase, Beta-glucanase and Hemicellulase

\section{Diets and management}

The experimental diets based on yellow corn, soybean meal and corn gluten meal were formulated to meet the nutrient requirements of broiler chickens according to (NRC, 1994). Composition and calculated analysis of the experimental diets are shown in Table (1).

Starter diet was offered from 0-2 weeks grower diet was fed from 3-4 weeks of age while finisher diets were fed from 5-6 weeks of age. Chicks of each replicate were allocated in a cage with slatted floor or iron in two-tier wire floor battery in an open house. Chickens had full access to water during the experimental period. Ambient temperature was kept about $32^{\circ} \mathrm{C}$ during the first week and then steadily reduced by $2^{\circ} \mathrm{C}$ weekly until fourth week to be about $24^{\circ} \mathrm{C}$, which continued as experiment ended ( 6 weeks of age).

\section{Growth performance}

The performance parameters included live body weight and feed intake which were determined at the end of finisher period. And then daily body weight gain (DWG), daily feed intake (DFI), feed conversion ratio (FCR), performance index (PI), production efficiency factor (PEF), protein conversion ratio (PCR) and Energy conversion ratio (ECR) were calculated correspondingly during the finisher period. 
Table (1): Feed ingredients and calculated chemical analyses of basal diets:

\begin{tabular}{lccc}
\hline Ingredient & $\begin{array}{c}\text { O- } 2 \text { weeks } \\
\text { Starter }\end{array}$ & $\begin{array}{c}3-4 \text { weeks } \\
\text { Grower }\end{array}$ & $\begin{array}{c}5-6 \text { weeks } \\
\text { Finisher }\end{array}$ \\
\hline Corn (grains) & 52.05 & 55.91 & 56.80 \\
Soybean Meal (44\%) & 31.50 & 30.00 & 28.25 \\
Corn Gluten Meal (62\%) & 7.20 & 4.86 & 4.40 \\
Soybean Oil & 3.00 & 3.65 & 5.00 \\
Wheat Bran & 2.00 & 1.50 & 2.00 \\
Di-Calcium Phosphate & 1.85 & 1.60 & 1.34 \\
Calcium Carbonate & 1.30 & 1.50 & 1.35 \\
Premix & 0.30 & 0.30 & 0.30 \\
Salt (NaCl) & 0.30 & 0.30 & 0.30 \\
DL-Methionine & 0.29 & 0.28 & 0.21 \\
L-Lysine HCL & 0.21 & 0.10 & 0.05 \\
Total & 100 & 100 & 100 \\
Chemical analysis (Calculated) & & & \\
Crude Protein\% & 23.00 & 21.00 & 20.00 \\
ME Kcal/ Kg diet & 3029 & 3076 & 3171 \\
Calcium\% & 1.00 & 1.01 & 0.90 \\
Available Phosphorus\% & 0.50 & 0.45 & 0.40 \\
Lysine\% & 1.30 & 1.15 & 1.06 \\
Methionine \& Cysteine\% & 0.97 & 0.93 & 0.84 \\
\hline Each $K$ of $p r i x$
\end{tabular}

Each $3 \mathrm{Kg}$ of premix contains: Vitamins: A: $12000000 \mathrm{IU}$; D3 $2000000 \mathrm{IU}$; E: $10000 \mathrm{mg} ; \mathrm{K3}: 2000 \mathrm{mg}$; B1:1000 mg, B2: $5000 \mathrm{mg}$; B6:1500 mg; B12: $10 \mathrm{mg}$; Biotin: $50 \mathrm{mg}$; Choline chloride: $250000 \mathrm{mg}$; Pantothenic acid: $10000 \mathrm{mg}$; Nicotinic acid: $30000 \mathrm{mg}$; Folic acid: $1000 \mathrm{mg}$; Minerals: Mn: $60000 \mathrm{mg}$; Zn: $50000 \mathrm{mg}$; Fe: $30000 \mathrm{mg}$; Cu: 10000 $\mathrm{mg}$; I: $1000 \mathrm{mg}$; $\mathrm{Se}: 100 \mathrm{mg}$ and $\mathrm{Co}: 100 \mathrm{mg}$.

\section{Slaughtering and carcass characteristics}

At end of experiment ( 6 weeks of age) four birds of each dietary treatment were randomly taken and slaughtered to determine the percentage of carcass edible parts (dressed carcass, liver, gizzard, heart and giblets), carcass inedible parts (Blood, feather, head, feet, viscera and body fats), carcass parts (Neck, wings, breast thighs and drumsticks) and some drumstick traits (skin, muscle and bone) percentages.

\section{Economic traits}

Economic parameters of production including feed cost, income and returns per birds were calculated. Economic efficiency is defined as net revenue (total revenue per chick (L.E.) - total costs per chick (L.E.)) Relative economic efficiency was calculated assuming control treatment $100 \%$.

\section{Statistical Analysis}

The collected data were subjected to two ways analysis of variance to detect effects of feed restriction (R) and feed supplementations $(\mathrm{F})$ and their interactions $\left(\mathrm{R}^{*} \mathrm{~F}\right)$ using the general liner model (GLM) procedure of SAS (SAS, 2002) according to the following model:

$$
Y i j k=\mu+R i+F j+(R * F) i j+\sum i j k,
$$

Where: Yijk $=$ trait measured, $\mu=$ Overall mean, $\mathrm{Ri}=$ feed restriction, $\mathrm{i}=(1,2), \mathrm{Fj}=$ feed supplementation, $\mathrm{j}=(1,2,3),(\mathrm{R} * \mathrm{~F}) \mathrm{ij}=$ interaction between feed restriction and feed supplementation, $\Sigma \mathrm{ijk}=$ experimental random error.

In addition, data of all experimental treatments were subjected to detect differences between all treatments and Duncan's multiple range test (Duncan, 1955) was used to separate means when separation was relevant. Statistical significance was accepted at probability level of $(\mathrm{P} \leq 0.05)$. 


\section{El-Faham et al.}

\section{RESULTS AND DISCUSSION}

The growth performance traits of broiler chicks fasted from feed for 6hrs/ day during fifth to sixth weeks of age and probiotic with enzymes preparation supplementation are shown in Tables (2 and 3).

Table (2): Effect of dietary treatments on live body weight (LBW), daily weight gain (DWG), daily feed intake (DFI) and feed conversion ratio (FCR) within 5 - 6 weeks of age.

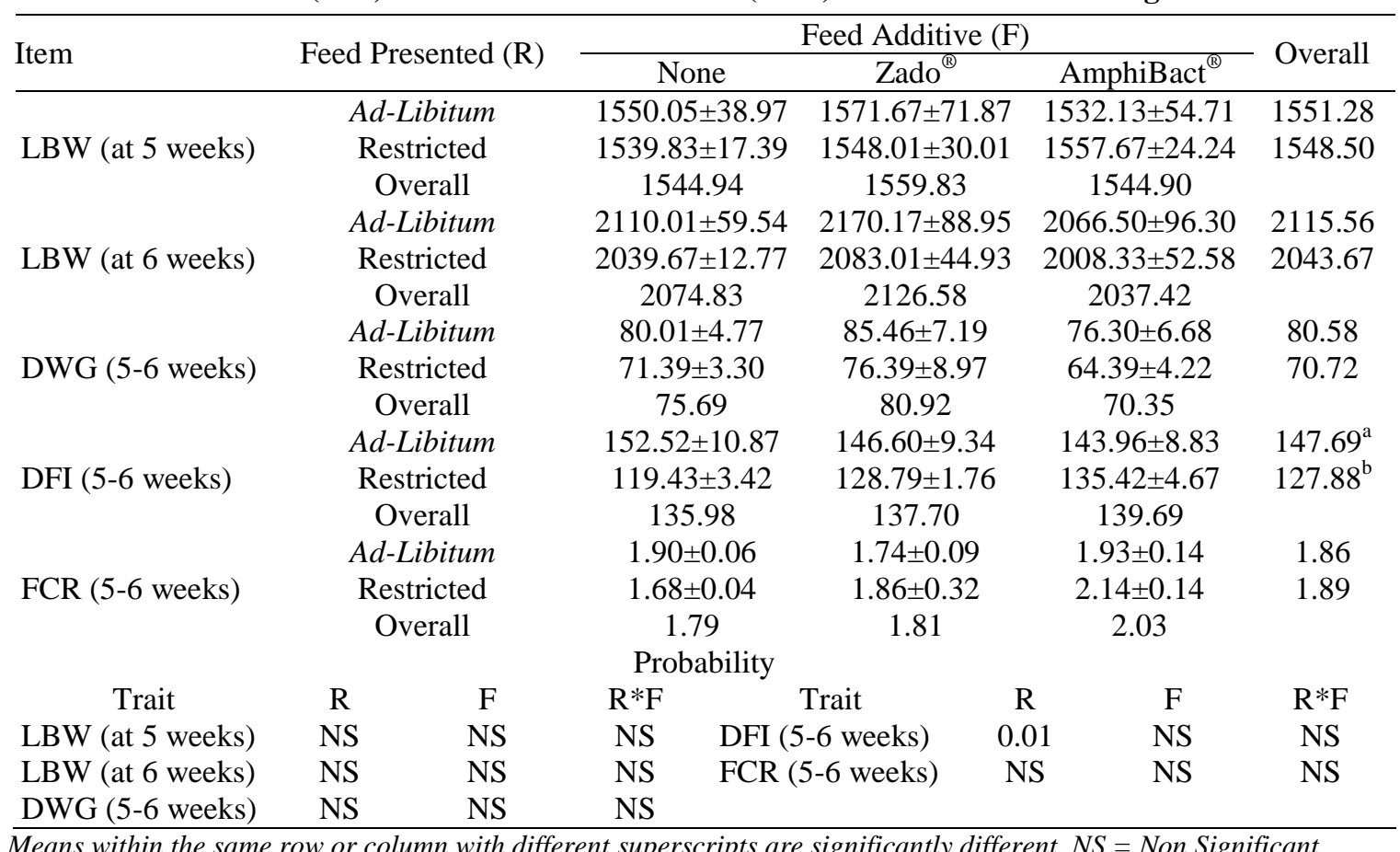

\section{Live body weight (LBW) and daily weight gain (DWG):}

The obtained data showed that there were insignificant differences in LBW and DWG among treatments during the studied period (5-6 weeks). It is clear observed that the broiler chicks fed ad-libitum always had insignificantly the highest LBW and DWG (at 6 weeks) of age, being 2115.56 and 80.58g, respectively. While those fed restricted diet had the lowest insignificant LBW and DWG compared with those fed adlibitum basal diet and the corresponding values were (2043.67 and 70.72g.) respectively.

Regarding the effect of interaction on the LBW and DWG, the results showed that the chicks fed basal diet (ad-libitum with Zado®) had the highest figures being (217.017 and 85.46g.) respectively, while those fed restricted diet with Amphi B act had the lowest figures, being (2008.33 and 64.39g.) respectively Besides, the differences between the two treatments were insignificant. Similar observations were reported by Hassanien (2011) who found that feed restriction systems did significantly affect live body weight and body weight gain. On the other hand, the obtained data disagree with those reported by other investigators, Fanooci and Torki (2010) and Ibrahim and Al-Hammami (2005), concluded that body weight of fasting broiler chicks ( 6 hours/ day fasting from 28-56 days of age) was depressed $(\mathrm{P}<0.05)$ at 5 weeks of age. According to Mahmood et al. (2005) and Gous and Cherry (2004) growth slow period of birds exposed to early feed restriction is typically followed by a rapid growth period when birds approach final growth stages. Faster body weight gain compensates for delayed growth that took place through early phases of feed restriction.

\section{Daily feed intake (DFI) and Feed conversion ratio (FCR):}

The results in Table (2) indicate that DFI per chick (5-6 weeks) were logically where the chicks fed $a d$ libitum consumed significantly higher $(\mathrm{P} \leq 0.05)$ feed than those fed restricted diets. The corresponding figures were (147.69 versus $127.88 \mathrm{~g} / \mathrm{c} / \mathrm{d})$ with significant differences between treatments. According to 
Scott et al. (1982) and Leeson and Summers (2005) birds have the ability to meet their energy requirements to certain extent by increasing feed consumption.

In the same order, average DFI was not affected by supplementation of probiotic with enzymes preparation (Zado® or Amphi B act) and the corresponding values were (135.98, 137.70 and $139.69 \mathrm{~g} / \mathrm{c} / \mathrm{d}$ ) when chicks fed diets supplemented with (None, Zado® or AmphiBact@) respectively. The effect of interaction showed the same trend since chicks fed different dietary treatments reflected insignificant differences in DFI and the overall mean were ranged between 152.52 and $119.43(\mathrm{~g} / \mathrm{c} / \mathrm{d})$ and the differences were insignificant. Feed conversion ratio (FCR) showed that, feed restriction, probiotic with enzymes supplementation or their interaction did not significantly affect feed conversion efficiency for all treatments. Many results are partially in agreement with results of this study. Petek (2000), Ozkan et al. (2003) and Hassanien and Elnagar (2011) reported that daily feed removal for 3, 4, 6 and 10h significantly reduced final body weight but had insignificant effects on feed intake, feed efficiency and carcass characteristics. Moreover, Saki (2005) and Khetani et al. (2008) concluded that body weight of broiler chicks at 42 days of age, weight gain, feed intake and feed conversion ratio were not affected by limited time feeding and there was any evidence of compensatory growth in the restricted birds.

On the other hand, Bruno et al. (2000), Lippens et al. (2000), Rincon and Leeson (2002) and Mansour et al. (2004) found that, chicks subjected to feed restriction, generally had a potential to utilize feed efficiently, because these birds tend to have relatively smaller body weights prior reaching market weight, therefore they minimize their needs.

In addition, the inclusion of prebiotic, probiotic or enzyme mixture in broiler diets did not have a significant effect on broiler performance, body weight gain, feed intake or feed conversion ratio [Biggs et al. (2007), Midilli et al. (2008), Taherpour et al. (2009), Cox et al. (2010), Rodriguez et al. (2012), Salem et al. (2012) and Elnagar (2012)].

Table (3): Effect of treatments on Performance index (PI), Production efficiency factor (PEF), Protein conversion ratio (PCR) and Energy conversion ratio (ECR).

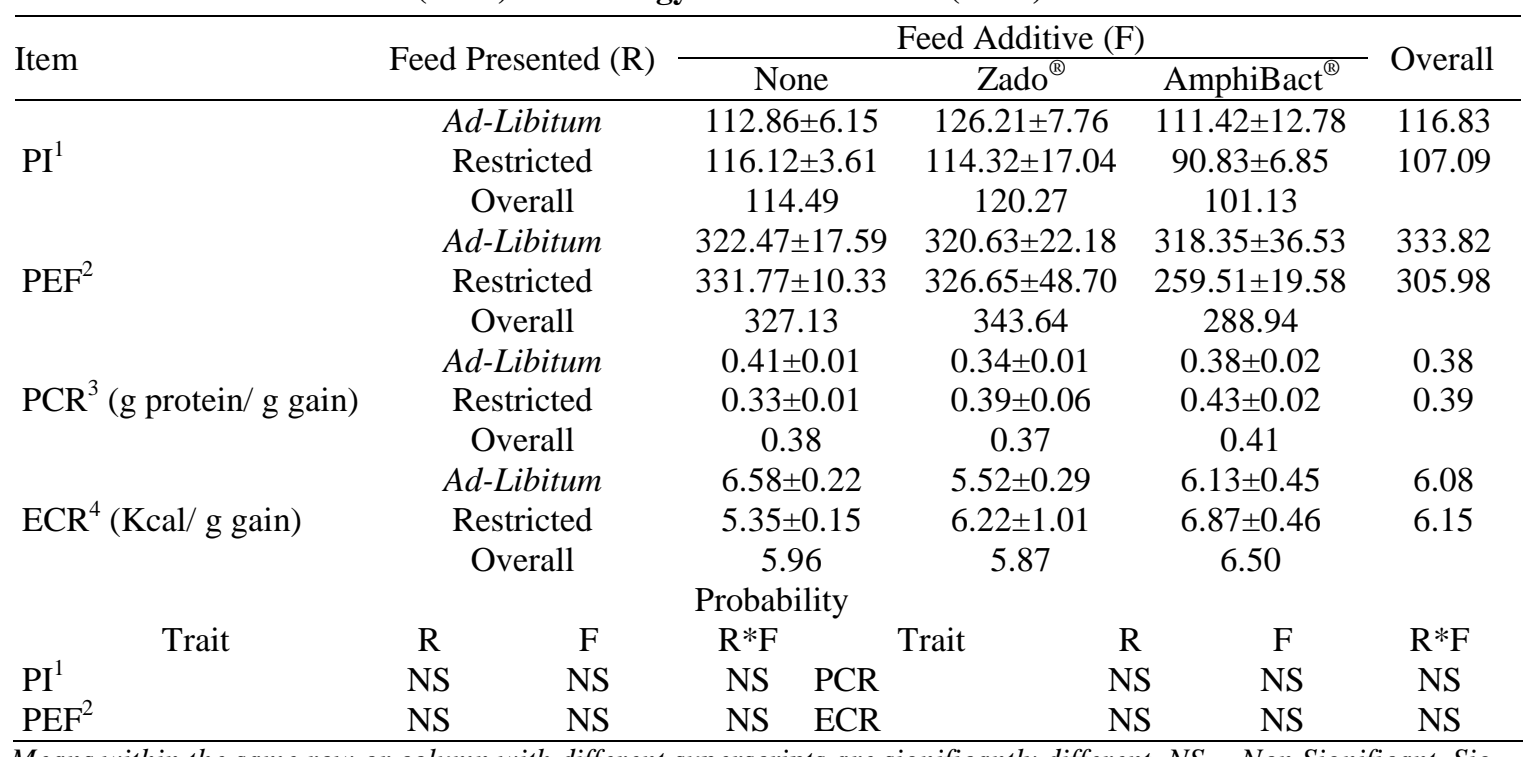

Means within the same row or column with different superscripts are significantly different. $N S=$ Non Significant, Sig. $=$ Significance, $*(P \leq 0.05), N S=$ Non-Significant, 1: North (1981), 2: Emmert (2000), 3: Calculated as (FCR * Crude Protein \%) / 100, 4: Calculated as (FCR * ME Kcal/ Kg diet) / 1000.

\section{Performance index (PI) and production efficiency factor (PEF):}

Table (3) showed the relationship between different treatments (feed restriction and probiotic supplementation) and PI or PEF. The obtained data showed that there were insignificant differences in PI and PEF during experimental period (5-6 weeks). Moreover, PI and PEF values were insignificantly decreased by feed restriction during experimental period. However, PI decreased by $8.3 \%$ (116.83 versus 107.09) compared with that fed ad-libitum and PEF showed similar trend (333.82 versus 305.98). Besides, 
the differences between the two treatments were insignificant. Moreover, feeding diets supplemented with Zado® $(0.5 \mathrm{Kg} /$ ton) gave the highest PI (120.27) or PEF (343.64) compared with other treatments (none or AmphiBact $\left.{ }^{\circledR}\right)$. On the same order, the lowest PI (101.13) or PEF (288.94) were detected for the chicks fed diets supplemented with AmphiBact ${ }^{\circledR}(0.5 \mathrm{Kg} /$ ton $)$ and differences between treatments were insignificant. Similar observations were reported by other investigators, Beshara et al. (2017) reported that feed restriction and supplementation diet with $0.4 \mathrm{~g}$ probiotics/ $\mathrm{Kg}$ had beneficial effects on health and performance index under environmental Egyptian condition. Also, Abdel-Azeem et al. (2009) found an improvement in the performance index for rabbits fed diets supplemented with Bio plus (probiotic).

\section{Protein conversion ratio (PCR) and Energy conversion ratio (ECR):}

The effect of different dietary treatments (feed restriction, probiotic with enzymes supplementation and their interaction) on PCR and ECR in broiler chicks was shown in Table (3). The obtained data showed that there were insignificant differences in PCR and ECR among treatments during the studied period (5-6 weeks). PCR values ranged between 0.33 and 0.43 , while ECR values ranged between 5.35 and 6.87 and broiler chicks fed restricted diet without supplementation gave the lowest figure while, chicks fed restricted diet with AmphiBact ${ }^{\circledR}$ supplementation had the highest figures and differences among treatments were insignificant.

\section{Carcass characteristics (edible and inedible parts):}

The effects of the experimental treatments on the carcass characteristics, carcass edible and inedible parts are listed in Tables (4 and 5).

Table (4): Effect of dietary treatments on carcass edible parts.

\begin{tabular}{|c|c|c|c|c|c|c|c|}
\hline \multirow{2}{*}{ Item } & \multirow{2}{*}{\multicolumn{2}{|c|}{ Feed Presented (R) }} & \multicolumn{4}{|c|}{ Feed Additive $(\mathrm{F})$} & \multirow{2}{*}{ Overal } \\
\hline & & & None & Zado $^{\circledR}$ & & AmphiBact $^{\circledR}$ & \\
\hline \multirow{3}{*}{ Dressed carcass \% } & $A d-L$ & & $72.75 \pm 1.10$ & $74.77 \pm 0.68$ & & $75.14 \pm 0.43$ & $74.22^{\mathrm{a}}$ \\
\hline & Res & & $72.87 \pm .0 .42$ & $72.80 \pm 0.25$ & & $72.14 \pm 0.88$ & $72.60^{\mathrm{b}}$ \\
\hline & $\mathrm{Ov}$ & & 72.81 & 73.78 & & 73.64 & \\
\hline \multirow{4}{*}{ Liver\% } & $A d-L$ & & $2.17 \pm 0.10$ & $1.97 \pm 0.09$ & & $1.90 \pm 0.22$ & 2.01 \\
\hline & Res & & $2.01 \pm 0.05$ & $2.15 \pm 0.25$ & & $2.01 \pm 0.05$ & 2.06 \\
\hline & $\mathrm{Ov}$ & & 2.09 & 2.06 & & 1.95 & \\
\hline & $A d-L$ & & $1.57 \pm 0.08$ & $1.27 \pm 0.07$ & & $1.36 \pm 0.11$ & 1.40 \\
\hline \multirow[t]{3}{*}{ Gizzard $\%$} & Res & & $1.53 \pm 0.09$ & $1.66 \pm 0.12$ & & $1.61 \pm 0.13$ & 1.60 \\
\hline & $\mathrm{Ov}$ & & 1.55 & 1.46 & & 1.48 & \\
\hline & $A d-L$ & & $0.59 \pm 0.04$ & $0.50 \pm 0.02$ & & $0.49 \pm 0.03$ & 0.53 \\
\hline \multirow[t]{3}{*}{ Heart $\%$} & Res & & $0.48 \pm 0.03$ & $0.51 \pm 0.06$ & & $0.64 \pm 0.06$ & 0.54 \\
\hline & $\mathrm{Ov}$ & & 0.53 & 0.50 & & 0.57 & \\
\hline & $A d-L$ & & $4.33 \pm 0.09$ & $3.74 \pm 0.17$ & & $3.74 \pm 0.16$ & 3.94 \\
\hline \multirow[t]{3}{*}{ Giblets\%* } & Res & & $4.03 \pm 0.10$ & $4.32 \pm 0.24$ & & $4.27 \pm 0.18$ & 4.20 \\
\hline & $\mathrm{Or}$ & & 4.18 & 4.03 & & 4.00 & \\
\hline & $A d-L$ & & $77.09 \pm 1.19$ & $78.51 \pm 0.79$ & & $78.89 \pm 0.27$ & 78.16 \\
\hline \multirow[t]{3}{*}{ Total edible Parts\%\# } & Res & & $76.90 \pm 0.32$ & $77.12 \pm 0.53$ & & $76.41 \pm 1.05$ & 76.81 \\
\hline & & & 76.99 & 77.82 & & 77.65 & \\
\hline & & & Probability & & & & \\
\hline Trait & $\mathrm{R}$ & $\mathrm{F}$ & $\mathrm{R} * \mathrm{~F}$ & Trait & $\mathrm{R}$ & $\mathrm{F}$ & $\mathrm{R} * \mathrm{~F}$ \\
\hline Dressed carcass $\%$ & 0.01 & NS & NS & Heart $\%$ & NS & NS & NS \\
\hline Liver\% & NS & NS & NS & Giblets\%* & NS & NS & NS \\
\hline Gizzard\% & NS & NS & NS & Total edible\%\# & NS & NS & NS \\
\hline
\end{tabular}

Means within the same row or column with different superscripts are significantly different. $N S=$ Non Significant,

$*$ Giblets $=$ Liver + Gizzard + Heart, \# Total edible Parts $=($ dressed carcass + giblets $)$.

The results in Table (4) show the relationship between dietary treatments and carcass edible parts. The percentages of dressed carcass for broiler chicks fed ad-libitum reflected significant differences than those in restricted feed.

The corresponding figures were 74.22 versus $72.60 \%$ with significant difference, these results agreed with Boostani et al. (2010) who reported that, the effect of feed restriction on carcass show that yield of 
R21-35d birds was lower as compared to the control treatment $(\mathrm{P}<0.05)$. While percentages of liver, gizzard, heart, giblets and total edible parts were almost the same when broiler chicks fed ad-libitum versus restricted fed and the corresponding values were 3.94 versus 4.20 for giblets $\%$ and 78.16 versus 76.81 for total edible parts $\%$, respectively and differences were insignificant. Similar observation was reported by other investigators, Palo et al. (1995), Mansour et al. (2004) and Hassanien and Elnager (2011). These authors concluded that restricting feed had no effects on carcass traits and relative weights of body organs. In the same order, present results illustrate no significant differences in carcass edible parts of broiler chickens in relation to feed supplementation of probiotic with enzymes preparations (Zado® or AmphiBact ${ }^{\circledR}$ ). The corresponding values for dressed carcass \% ranged between 72.81 and $73.78 \%$, while total edible parts $\%$ ranged between 76.99 and $77.82 \%$. Similar observation has been reported by SayyaZadoeh et al. (2006), Sherif (2009) and Elnagar (2012). They concluded that the addition of either enzyme mixture, commercial probiotic or their combination had no significant effect on the percentage of dressing, gizzard, heart, liver or abdominal fat.

Table (5) shows the effect of feed restriction and probiotic with enzymes preparation supplementation on carcass inedible parts for the chicks at the end of 6 weeks of age. Different experimental treatments had no significant effect on studied parameters (blood, feather, head, feet, viscera, body fats and total inedible parts) percentages.

Table (5): Effect of dietary treatments on carcass inedible parts.

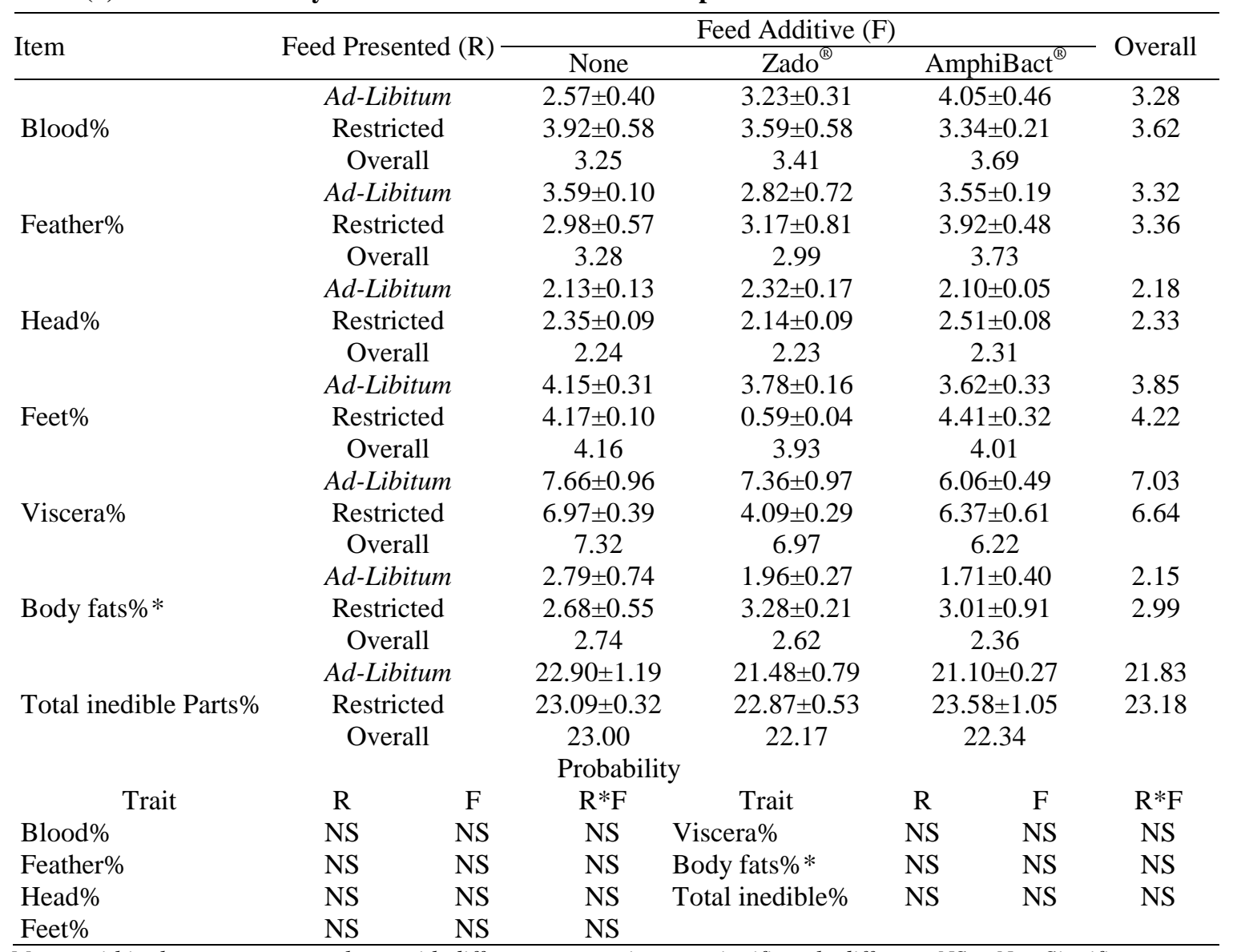

Means within the same row or column with different superscripts are significantly different. $N S=$ Non Significant. $*$ Bodys fats $=$ Abdominal fat + Gizzard fat + Heart fat .

The corresponding values for body fats percentages ranged between 1.71 and $3.28 \%$, while total inedible parts percentage ranged between 21.10 and $23.58 \%$ and the differences were insignificant. Similar observations have been reported by Lebbie et al. (1980) and Mansour et al. (2004) as they suggested the absence of any significant differences in fat deposition between birds on ad-libitum and 90 or $85 \%$ of adlibitum, due to excessive metabolizable energy intake in regard to normal requirements. 


\section{Carcass cuts and drumstick traits:}

Effect of different dietary treatments (feed restriction, probiotic with enzyme supplementation and their interaction) on relative weights of carcass cuts of broiler chicks are presented in Table (6). Most of studied traits (i.e. wings, breast, thighs and drumsticks, percentages) were not significantly affected by the treatments.

The corresponding values ranged between (9.70 and 10.62) for wings\%; while ranged between $(39.10$ and 42.50) for breast\%; ranged between (27.63 and 29.19) for thigh\% and ranged between (12.90 and 13.89) for drumstick\%, however, the differences were insignificant. Results agree with those obtained by ElSagheer and Makled (2005) who found that no significant differences in the percentages of femurs, breast, wings and breast were observed between full-fed and all restricted broilers.

Table (6): Effect of dietary treatments on carcass cuts.

\begin{tabular}{|c|c|c|c|c|c|c|c|c|}
\hline \multirow{2}{*}{ Item } & \multirow{2}{*}{\multicolumn{2}{|c|}{ Feed Presented (R) }} & \multicolumn{5}{|c|}{ Feed Additive (F) } & \multirow{2}{*}{ Overall } \\
\hline & & & \multicolumn{2}{|c|}{ None } & $\mathrm{Zado}^{\circledR}$ & & AmphiBact $\left.^{(}\right)$ & \\
\hline & \multicolumn{2}{|c|}{ Ad-Libitum } & \multicolumn{2}{|c|}{$6.28 \pm 0.59$} & $6.46 \pm 0.14$ & & $6.68 \pm 0.40$ & $6.47^{b}$ \\
\hline \multirow[t]{3}{*}{ Neck\% } & \multicolumn{2}{|c|}{ Restricted } & \multicolumn{2}{|c|}{$8.16 \pm 0.66$} & $7.71 \pm 0.74$ & & $7.56 \pm 0.40$ & $7.81^{\mathrm{a}}$ \\
\hline & \multicolumn{2}{|c|}{ Overall } & \multicolumn{2}{|c|}{7.22} & 7.08 & & 7.12 & \\
\hline & \multicolumn{2}{|c|}{ Ad-Libitum } & \multicolumn{2}{|c|}{$10.01 \pm 0.30$} & $9.70 \pm 0.24$ & & $10.11 \pm 0.14$ & 9.94 \\
\hline \multirow[t]{3}{*}{ Wings \% } & \multicolumn{2}{|c|}{ Restricted } & \multicolumn{2}{|c|}{$10.62 \pm 0.49$} & $10.51 \pm 0.30$ & & $10.28 \pm 0.41$ & 10.47 \\
\hline & \multicolumn{2}{|c|}{ Overall } & \multicolumn{2}{|c|}{10.32} & 10.11 & & 10.20 & \\
\hline & \multicolumn{2}{|c|}{ Ad-Libitum } & \multicolumn{2}{|c|}{$41.75 \pm 2.40$} & $41.88 \pm 0.65$ & & $42.50 \pm 0.78$ & 42.04 \\
\hline \multirow[t]{3}{*}{ Breast $\%$} & \multicolumn{2}{|c|}{ Restricted } & \multicolumn{2}{|c|}{$39.12 \pm 0.47$} & $39.67 \pm 1.08$ & & $39.10 \pm 1.07$ & 39.29 \\
\hline & \multicolumn{2}{|c|}{ Overall } & \multicolumn{2}{|c|}{40.43} & 40.77 & & 40.80 & \\
\hline & \multicolumn{2}{|c|}{ Ad-Libitum } & \multicolumn{2}{|c|}{$28.42 \pm 0.95$} & $28.10 \pm 0.21$ & & $27.63 \pm 0.49$ & 28.05 \\
\hline \multirow[t]{3}{*}{ Thighs $\%$} & $\mathrm{Re}$ & & 29.19 & 1.18 & $28.73 \pm 0.36$ & & $29.16 \pm 1.17$ & 29.02 \\
\hline & & & & & 28.41 & & 28.39 & \\
\hline & $A d-$ & tum & 13.52 & 1.05 & $13.85 \pm 0.49$ & & $13.07 \pm 0.22$ & 13.48 \\
\hline Drumsticks\% & $\operatorname{Re}$ & & 12.90 & 0.53 & $13.37 \pm 0.44$ & & $13.89 \pm 0.21$ & 13.39 \\
\hline & & & & & 13.61 & & 13.48 & \\
\hline & $A d-$ & tum & 10.65 & 1.42 & $10.12 \pm 1.30$ & & $9.37 \pm 1.06$ & 10.05 \\
\hline Drumstick skin\% & $\operatorname{Re}$ & & 8.52 & 0.97 & $11.97 \pm 1.35$ & & $9.97 \pm 1.80$ & 10.15 \\
\hline & & & & & 11.04 & & 9.67 & \\
\hline & $A d-$ & tum & 66.05 & 1.50 & $68.21 \pm 1.22$ & & $68.70 \pm 0.92$ & 67.65 \\
\hline Drumstick muscle\% & $\mathrm{Re}$ & & $67.1 \mathrm{C}$ & 0.84 & $63.98 \pm 1.08$ & & $67.24 \pm 1.40$ & 66.14 \\
\hline & & & & & 66.10 & & 67.97 & \\
\hline & $A d-$ & tum & 23.29 & 1.52 & $21.65 \pm 0.33$ & & $21.92 \pm 1.86$ & 22.29 \\
\hline Drumstick bone\% & $\mathrm{Re}$ & & 24.28 & 0.23 & $24.04 \pm 0.42$ & & $22.78 \pm 0.49$ & 23.70 \\
\hline & & & & & 22.84 & & 22.35 & \\
\hline & & & & ability & & & & \\
\hline Trait & $\mathrm{R}$ & $\mathrm{F}$ & $\mathrm{R} * \mathrm{~F}$ & & & $\mathrm{R}$ & $\mathrm{F}$ & $\mathrm{R} * \mathrm{~F}$ \\
\hline Neck\% & 0.01 & NS & NS & Drum & $s \%$ & NS & NS & NS \\
\hline Wings $\%$ & NS & NS & NS & Drum & skin $\%$ & NS & NS & NS \\
\hline Breast $\%$ & NS & NS & NS & Drum & muscle $\%$ & NS & NS & NS \\
\hline Thighs $\%$ & NS & NS & NS & Drum & bone $\%$ & NS & NS & NS \\
\hline
\end{tabular}

Dietary treatments had no influence on drumstick traits; data showed that there was no significant difference between treatments in drumstick (skin, muscle and bone) percentage, Table (6). Drumstick skin\% ranged between 8.52 and 11.97; while muscle \% ranged between 63.98 and 68.70 and bone $\%$ ranged between 21.65 and 24.28 with no significant differences between treatments.

\section{Economic evaluation:}

Data for economic evaluation are summarized in Table (7). Results of economic efficiency and relative economic efficiency estimated for experimental diets are based on recent local market prices for feed 
ingredients and selling price of live broiler chicks. Chicks fed diets supplemented with (Zado®, $0.5 \mathrm{Kg} /$ ton) in ad-libitum or restricted regime had the best relative economic efficiency values being 120.14 and $124.76 \%$, respectively.

On the other hand, mean economic efficiency of all restricted-fed groups increased relatively about $3 \%$ as compared with the ad-libitum groups. Similar observations were reported by Sagheer and Makled (2005) who reported that, the removal of feed for 6 hours per day recorded better economically efficient values as compared with other restricted fed groups. Alternatively, El-Deek et al. (2013) found that the highest economic efficiency value was recorded with group fed diet supplemented with probiotic.

Table (7): Effect of dietary treatments on economic traits.

\begin{tabular}{|c|c|c|c|c|c|c|}
\hline \multirow{4}{*}{ Item } & \multicolumn{6}{|c|}{ Dietary Treatments } \\
\hline & \multicolumn{3}{|c|}{ Ad-Libitum Feeding } & \multicolumn{3}{|c|}{ Restricted Feeding } \\
\hline & No - & Zado 0.5 & AmphiBact & No - & Zado 0.5 & AmphiBact \\
\hline & Additive & $\mathrm{Kg} / \mathrm{Ton}$ & $0.5 \mathrm{Kg} / \mathrm{Ton}$ & Additive & $\mathrm{Kg} / \mathrm{Ton}$ & $0.5 \mathrm{Kg} / \mathrm{Ton}$ \\
\hline \multirow{2}{*}{ Average feed consumption $(\mathrm{Kg})$} & 1.06 & 1.02 & 1.01 & 0.84 & 0.90 & 0.94 \\
\hline & \pm 0.07 & \pm 0.06 & \pm 0.06 & \pm 0.02 & \pm 0.01 & \pm 0.03 \\
\hline \multirow{2}{*}{ Total cost* $(\mathrm{LE})$} & 46.53 & 46.88 & 45.80 & 44.81 & 44.65 & 44.56 \\
\hline & \pm 1.07 & \pm 2.08 & \pm 1.54 & \pm 0.33 & \pm 0.34 & \pm 1.51 \\
\hline \multirow{2}{*}{ Feed cost (LE) } & 6.78 & 6.58 & 6.49 & 5.31 & 5.78 & 6.10 \\
\hline & \pm 0.48 & \pm 0.41 & \pm 0.39 & \pm 0.15 & \pm 0.07 & \pm 0.21 \\
\hline \multirow{2}{*}{ Live body weight $(\mathrm{Kg})$} & 2.11 & 2.17 & 2.06 & 2.04 & 2.08 & 2.01 \\
\hline & \pm 0.06 & \pm 0.08 & \pm 0.09 & \pm 0.01 & \pm 0.04 & \pm 0.05 \\
\hline \multirow{2}{*}{ Total return $^{\#}$ (LE) } & 52.75 & 54.25 & 51.66 & 50.99 & 52.07 & 50.21 \\
\hline & \pm 1.48 & \pm 2.22 & \pm 2.40 & \pm 0.31 & \pm 1.12 & \pm 1.31 \\
\hline \multirow{2}{*}{ Net return (LE) } & 6.21 & 7.37 & 5.86 & 6.18 & 7.42 & 5.65 \\
\hline & \pm 0.49 & \pm 0.97 & \pm 0.99 & \pm 0.45 & \pm 0.95 & \pm 0.55 \\
\hline \multirow{2}{*}{ Economic efficiency } & 13.29 & 15.97 & 12.57 & 13.82 & 16.59 & 12.87 \\
\hline & \pm 0.83 & \pm 2.43 & \pm 1.88 & \pm 1.09 & \pm 2.09 & \pm 1.56 \\
\hline Relative economic efficiency & 100.00 & 120.14 & 94.55 & 103.97 & 124.76 & 96.79 \\
\hline Mean economic efficiency & \multicolumn{3}{|c|}{$104.89(100 \%)$} & \multicolumn{3}{|c|}{$108.50(103 \%)$} \\
\hline
\end{tabular}

* Calculated as of price of chickens at trial start point (5 weeks of age).

\# According to the local price of $\mathrm{Kg} \mathrm{LBW}$, which was $25.00 \mathrm{L.E}$.

\section{CONCLUSION}

Based on results of the current study, it would be concluded that supplementing broiler chicks under $a d$ libitum or restricted-fed regime with $(\mathrm{Zado} \circledast, 0.5 \mathrm{Kg} / \mathrm{ton})$ could improve performance and economic efficiency, during 5-6 weeks of age.

\section{REFERENCES}

Abd El-Galil, K.; Mona M. Hassan; Hend A. Mahmoud; K.M. Abu El-Soud and A.A. Abd El-Dayem (2017). Utilization of olive pulp meal as A non-traditional feedstuff in growing local hens feeding under desert conditions. 37: (IV): 1237-1248.

Abdel-Azeem, F.; N.A. Hashim; Y.K.E.H. Badwi and A. Farid (2009). Comparative study between probiotic (Bioplus 2B) and antibiotic (lincofeed) on the performance of growing rabbits. Egyptian. J. Rabbit Sci. 19(1): 7-22.

Awad, W.A.K.; Ghareeb; S. Abdel-Raheem and J. Böhm (2009). Effects of dietary inclusion of probiotic and symbiotic on growth performance, organ weights and intestinal histomorphology of broiler chickens Poult. Sci. 88: 49-55. 


\section{El-Faham et al.}

Azarnik, A.; M. Bojarpour; M. Eslami; M.R. Ghorbani and K. MirZadoeh (2010). The effect of different levels of diet protein on broilers performance in ad-libitum and feed restriction methods. J. of Animal and Vet. Advances 9(3): 631-634.

Beshara, M.M.; M.A. Ragab; A. El-; M.I. El-Desoky; H.N. Fahim; A.M. El-Fhhat; A.A. Alazab and A.A. El-gamal (2017). Effect of feed restriction with supplementation of probiotic on productive and economical performance in local growing rabbits. Egypt. Poult. Sci. 37: 407-431.

Biggs P. and C.M. Parsons (2008). The effect of Grobiotic-P growth performance, nutrient digestibilities and cecal microbial populations in young chicks. Poult. Sci. 87: 1796-1803.

Biggs, P.; C.M. Parsons and G.C. Fahey (2007). The effects of several obgosaccharides on growth performance, nutrient digestibilities and cecal microbial populations in young chicks Poult. Sci. (86): 2327-2336.

Boostani, A.; A. Ashayerizadeh; H.R. Mahmoodian Fard and A. Kamalzadeh (2010). Comparison of the effects of several feed restriction periods to control ascites on performance, carcass characteristics and hematological indices of broiler chickens. Bra. J. Poult. Sci. 12: 171-177.

Bruno, L.D.G.; R.L. Furlam; E.B. Malheiros and M. Macari (2000). Influence of early quantitative food restriction on long bone growth at different environmental temperatures in broiler chickens. British Poult. Sci. 41(4): 389-394.

Cowieson, A.J. and O. Adeola (2005). Carbohydrates, protease and phytase have an additive beneficial effect in nutritionally marginal diets for broilers chicks. Poultry Sci. 84: 1860-1867.

Cowieson, A.J.; D.N. Singh and O. Adeola (2006). Prediction of ingredient quality and the effect of a combination of xylanase, amylase, protease and phytase in the diets of broiler chicks. 1-Growth performance and digestible nutrient intake. British Poult. Sci. 47: 477-489.

Cox, C.M.; L.H. Stuard; S. Kim; A.P. McElory; M.R. Bedford and R.A. Dalloul (2010). Performance and immune responses to dietary $\beta$-glucan in broiler chicks. Poult. Sci. 89: 1924-1933.

Czerwinski, J.; O. Hojbrg; S. Smulikornska; R.M. Engberg and A. Mieczkowska (2010). Influence of dietary pens and organic acids and probiotic supplementation on performance and caecal microbial ecology o broiler chickens. Br. Poult. Sci. 51(2): 258-269.

Duncan, D.B. (1955). Multiple range and Multiple F tests. Biometrics, 11: 1-42.

El-Deek, A.A.; M.A. Albanoby and M.K. Abou El-Naga (2013). Evaluation of super action probiotic as a natural growth promoter for growing rabbit. Egypt. Poult. Sci. 33: 407-419.

Elnagar, S.H.M. (2012). Impact of enzyme mixture, probiotic or both on performance of broilers fed sorghum-based diets. Egypt. J. Nutr. and feeds 15 (1): 123-131.

El-Sagheer, M. and M.N. Makled (2005). Effect of duration of feed withdrawal versus ad libitum feeding during high environmental temperature of broiler chicken performance. Egypt Poult. Sci. 25(11): 333350 .

Emenalom, O. (2004). Comparative performance of broiler chicks fed diets containing differently processed mucuna pruriens seed meals. Nigerian J. of Anim. Prod. 31: 12-16.

Emmert, J. (2000). Efficiency of phase feeding in broilers. Proceeding, California Animal Nutrition Conference. Fresno California, USA.

Fanooci, M. and M. Torki (2010). Effects of qualitative dietary restriction on performance, carcass characteristics white blood cell count and humoral immune response of broiler chicks. Global veterinaria, 4(3): 277-282.

Gous, R.M. and R. Cherry (2004). Effect of body weight, and lighting regimen and growth curve to, 20 weeks on laying performance in broiler breeders. Br. Poult. Sci., 454: 4(4) 5-452.

Hassanien, H.H.M. (2011). Productive performance of broiler chickens as affected by feed restriction systems. Asian J. of Poult. Sci. 5(1): 21-27.

Hassanien, H.H.M. and Sanaa H.M. Elnagar (2011). Effect of feed restriction system at different age periods on broilers performance. Egypt J. Nutri. And feeds, 14(3): 529-536. 
Ibrahim, D.K. and A.H.K. Al-Hammami (2005). Effect of adding different level of glucose to drinking water during fasting on some productive and physiological characteristics of male broilers exposed to heat stress. Egypt. Poult. Sci. 25: 895-910.

Khetani, T.L.; T.T. Nkukwana; M. Chimonyo and V. Muchenje (2008). Effect of quantitative feed restriction on broiler performance. Trop. Anim. health and prod. (41): 379-384.

Lebbie, S.H.B.; K. Benyi and A.A. Ademosum (1980). The effect of feeding regimen and stocking rate on the performance of medium bodied layers in the humid tropics. Br. Poult. Sci. 22: 415-421.

Leeson, S. and J.D. Summers (2005). Feedings programs for broiler chickens: growth restriction in "Commercial poultry Nutrition", 3rd Edition, University Books, Guelph, Ontario.

Lippens, M.; G. Room; G. De Groote and E. Decuypere (2000). Early and temporary quantitative food restriction of broiler chickens. 1. Effects on performance characteristics, mortality and meat quality. $\mathrm{Br}$. Poult. Sci. 41(3): 343-354.

Longe, O.G. (2006). Poultry: Treasure in a chest. Inaugural Lecture, University of Ibadan, Nigeria 1-42.

Mahmood, S.; S. Hassan; F. Ahmed; M. Ashraf; M. Alam and A. Muzaffar (2005). Influence of feed withdrawal for different durations on performance of broilers in summer. Int. J. Agric. Biol., 7: 975-978.

Mansour, K.M.; Salwa, S. Siam and A.M.R. Osman (2004). Effects of age and quantitative feed restriction prior slaughtering on the performance, carcass characteristics and some blood constituents of broilers. Egypt Poult. Sic. 24(11): 509-522.

Midilli, M.; M. Alp; N. Kocabagh; Ö.H. Muglah; N. Turan; H. Yilmaz and S. Cakir (2008). Effects of dietary probiotic and prebiotic supplementation on growth performance and serum IgG concentration of broilers. South African J. Animal Sci. 38(1).

North, M.O. (1981). Commercial chicken. Production Annual, 2nd Edition, Av., Publishing Company I.N.C., West Post. Connecticut, USA.

NRC (1994). National Research Council. Nutrient Requirements of Poultry 9th Rev. Ed. Composition of poultry feedstuffs. National Academy Press, Washington, DC, USA. p.p. 61-75.

Ozkan, S.; Y. Akbas; O. Altan; A. Altan; V. Ayhan and K. Ozkan (2003). The effect of short term fasting on performance traits and rectal temperature during the summer season. Br. Poult. Sci. (44): 88-95.

Palo, P.E.; J.L. Sell; F.J. Piquer; L. Vilaseca and M.F. Soto-Salonova (1995). Effect of early nutrient restriction on broiler chicken.2. performance and digestive enzyme activities. Poult. Sci. 74: 1470-1483.

Petek, K. (2000). The effect of feed withdrawal during the day on some production traits and blood parameters of broilers. Turkish J. of vet. And anim. Sci. (24): 447-452.

Rahimi, S.; J.L. Grimes; O. Fletcher; E. Oviedo and B.W. Sheldon (2009). Effect of a direct-fed microbial (primalac) on structure and ultrastructure of small intestine in turkey poults. Poult. Sci. 88: 491-503.

Rahimi, S.; Z. Moghadam Shiraz; T. Zahraei Salehi, M.A. Karimi Torshizi and J.L. Grimes (2007). Preventation of salmonella infection in poultry by specific egg-derived antibody. Int. J. Poult. Sci. 6: 230236.

Rincon, M.U. and S. Leeson (2002). Quantitative and qualitative feed restriction on growth characteristics of male broiler chickens. Poult. Sci. (81): 679-688.

Rodriguez, M.L.; A. Rebole; S. Velasco; L.T. Ortiz; J. Trevino and C. Abzueta (2012). Wheat and barleybased diets with or without additives influence broiler chicken performance, nutrient digestibility and intestinal microflora. J. Sci. Food Agric., 92(1): 184-90.

Saki, A.A. (2005). Effect of post-hatch feeding on broiler performance. Int. J. Poult. Sci. 4(1): 4-6.

Salem, F.M.; H.A. El-Alaily; A.A. Hemid; N.M. El-Medany and K. Abd El-Galil (2012). Effects of probiotic and prebiotic supplementation on growth performance and blood metabolites in broiler chicks reared in batteries. Egypt J. Nutri. and Feeds 15(2): 335- 349.

SAS (2002). SAS/ STAT User, S Guide: Statistics. Ver. 8.2, SAS Institute Inc., Cary. NC. 


\section{El-Faham et al.}

Saxowsky, D.M. and M.R. Duncan (1998). Understanding agricultures transition into the 21st century: Challenges, opportunities, consequences and alternatives (Fargo, Department of Agricultural Economics North Dakota State University).

SayyaZadoeh, H.; G. Rahimi and M. Rezaei (2006). Influence of enzyme supplementation of maize, wheat and barley-based diets on the performance of broiler chickens. Pak. J. Biol. Sci., 9(4): 616-621.

Scott, M.L.; M.C. Nesheim and R.J. Young (1982). Nutrition of the chicken. M.L. Scott and Associates, Ithace, New York, USA.

Sherif, Kh. El. (2009). Performance of broiler chicks fed plant protein diets supplemented with commercial enzymes. J. Agric. Sci., Mansoura Univ., 34(4): 2819-2834.

Taherpour, K.; H. Moraved; M. ShivaZado; M. Adibmoradi and B. Yakhchali (2009). Effects of dietary probiotic, prebiotic and butyric acid glycerides on performance and serum composition in broiler chickens. African J. Biotech. 8(10): 2329-2334.

Yu, B.; S.T. Wu; C.C. Liu; R. Gauthier and P.W.S. Chiou (2007). Effect of enzyme inclusion in a maize soybean diet on broiler performance. Anim. feed Sci. Technology 134: 283-294.

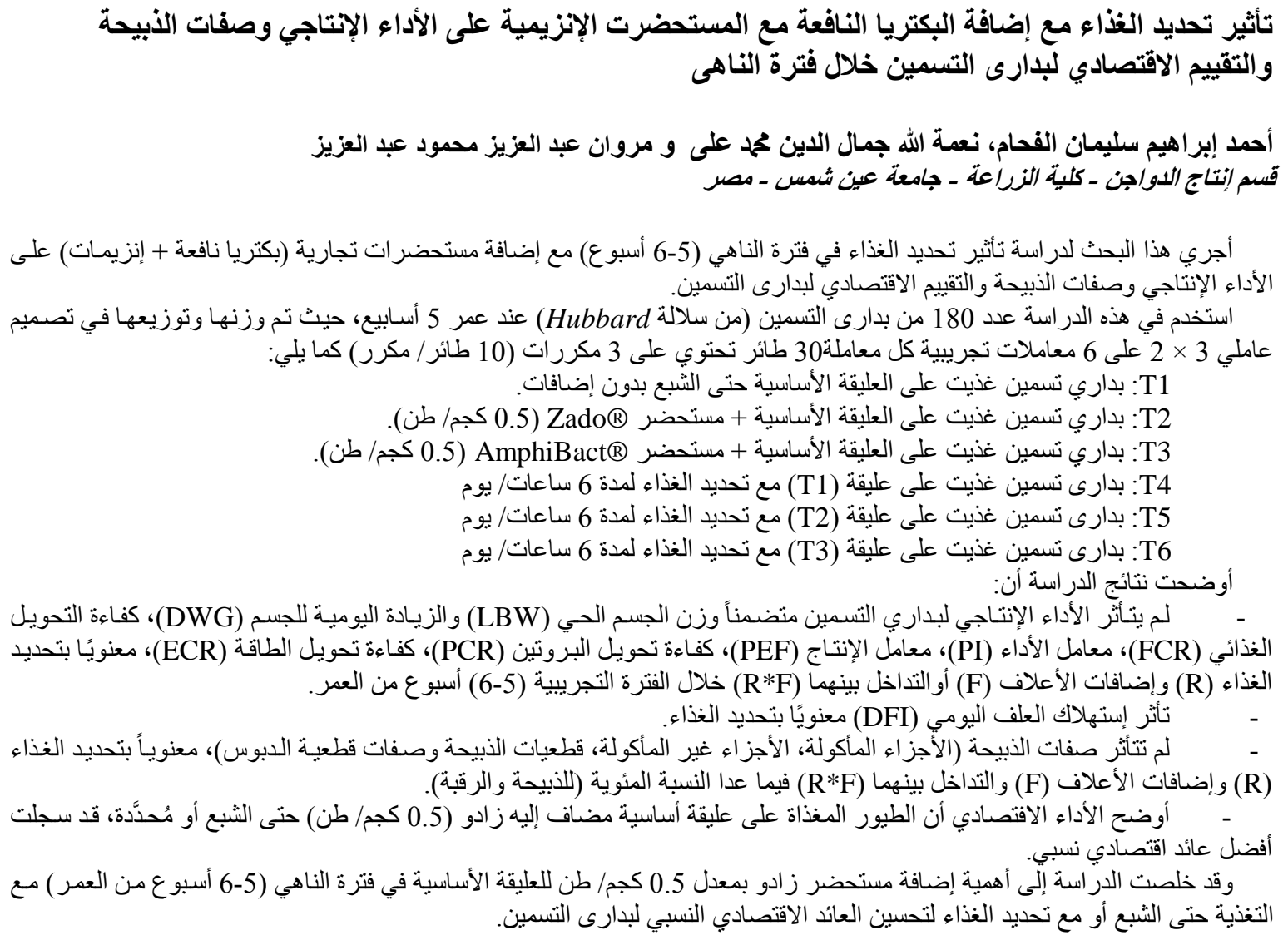

